\title{
Sustainable Halal? The Intersection of Halal, Organic and Genetically Engineered Food in Turkey
}

\author{
Nurcan Atalan-Helicke \\ Environmental Studies and Sciences, Skidmore College, US \\ natalanh@skidmore.edu
}

\begin{abstract}
Despite standardization initiatives among states, businesses and non-profit agencies, the understanding and practice of halal requirements vary. This fragmentation of halal certification is particularly significant in terms of genetically engineered food. Studies in both global North and South show that women consumers are more concerned about food choices. This paper examines the convergence of halal and organic through genetically engineered food with recourse to women consumers' definitions of 'wholesome food' in Turkey. Using data from a total 13 focus groups carried in the cities of Ankara and Konya in the summer of 2015, and in the cities of Ankara and Balikesir in the summer of 2019, the paper examines the concerns of women consumers about food in a Muslim majority country fully integrated into globalized markets. It also questions how women consumers negotiate their food choices particularly in relation to genetically engineered food, halal and organic food. The paper argues that both secular and devout Muslim women consumers as mothers have growing concerns in feeding their family with clean and healthy food. However, halal certified food does not address their expectations about 'wholesome food'. The discussions about the convergence of halal, organic and genetically engineered food highlight the tensions in the alternative food movement about what clean and good food look like.
\end{abstract}

\section{Keywords}

halal - genetically engineered food - food choice - women consumers - Turkey 


\section{Introduction}

Changing ingredients and processes in agri-food systems create new questions for Muslims who would like to live according to Islamic principles because these complex issues and ingredients require interpretation and application (Fischer 2011: 15-17; Armanios and Ergene 2018: 40). Genetically engineered (GE) food ${ }^{1}$ is one of these controversial topics for Muslim consumers who not only have broader concerns about the agri-food system, such as the traceability of food, health risks, and ethics, but also lack trust in the state and markets (Atalan Helicke 2015: 672). In guiding their food choices, consumers use numerous strategies for assurances. Food certified as halal, permissible according to Islam, possesses a trust attribute, and this helps many Muslim consumers in their choices.

Of the growing global Islamic economy, $63 \%$ of the expenditures, or $\$ 1.4$ trillion, was on halal food and beverages in 2018 (Dinar Standard 2019). Consumer perceptions of halal food demonstrate that Muslim consumers associate halal, its nature, and its technique of processing (involving the ingredients, handling, and use of various methods) from beginning to end - with cleanliness and food safety (Mutmainah 2018). The additional and more complicated principle of tayyib, which is also used in connection to halal food, refers to whether food is wholesome (Armanios and Ergene 2018: 191-192). Keeping tayyib requires a 'higher degree of vigilance than merely eating halal' (Koenig 2008: 82). For instance, industrially produced beef can be halal certified if slaughtered following Islamic principles and hygienic practices. However, because Islamic principles forbid cruelty to living beings and mandate that meat come from animals raised in sanitary and humane conditions, some Muslim consumers are concerned that halal certified meat coming from concentrated animal factory operations (CAFOs) compromises the integrity of these values (Friedlander 2014). From this perspective, the concern for quality and permissibility is not just about the end product and how animals are slaughtered, which is the main focus of many halal standards and certifiers, but how well the animals lived (Armanios and Ergene 2018: 195). A tayyib-halal ethos can extend beyond the most legalistic definition of the term halal because it has developed in response to not only dubious slaughterhouse procedures, but

1 Genetic engineering and genetic modification are often used interchangeably to refer to biotechnology applications in agriculture. Following the USA Food and Drug Administration's definition, this paper defines genetic engineering as related to the use of recombinant DNA and cell fusion techniques to introduce new characteristics or traits into an organism (FDA 2O18). 
also in response to known human labor abuses and biochemical additives in food production (Armanios and Ergene 2018: 191). While not all Muslims agree with these broader interpretations, the tayyib-halal lens helps some Muslim consumers bridge their identity and faith with ethical values.

This paper examines the convergence of halal and organic through GE food with recourse to women consumers' definitions of 'wholesome food' in Turkey. Two questions guided this research: What are the concerns of consumers about food in a Muslim majority country fully integrated into globalized markets? How do women consumers negotiate their food choices particularly in relation to GE food, halal and organic food? The paper argues that both secular and devout Muslim mothers have growing concerns in feeding their family with clean and healthy food. However, halal certified food does not address their expectations about GE-free and wholesome food. The paper's findings on the convergence of halal with organic food can be fruitful to capture Muslim imaginaries about the food system. While these discussions are likely to bring about non-Western imaginaries to alternative food discussions about what clean and good food look like, they also allow for the possibilities of sustainable and ethical food consumption.

Despite consensus building efforts by the international Muslim business community, such as the World Halal Forum, and Muslim theologians, there are multiple perspectives about the halal status of GE food (Armanios and Ergene 2018: 199; Atalan Helicke 2015: 671). Moreover, the scientific complexity of genetic engineering in agriculture and the uncertainty of health impacts of GE food raise questions for Muslim consumers, businesses and associations. Out of the 57 members of Organization of Islamic Cooperation (OIC) countries, only four countries currently cultivate GE crops (Pakistan and Sudan grow GE cotton since 2010, Bangladesh grows GE eggplant, and Indonesia grows GE sugarcane). Other OIC members, such as Malaysia, Egypt and Turkey, however, have approvals for import of GE crops for use as animal feed and/or food processing (ISAAA 2019a). ${ }^{2}$ GE crops, such as corn and soybeans, are used

2 Among oIC members, Burkina Faso cultivated GE cotton from 2008 until 2016, and there is research and development in the form of confined field testing and contained research in several countries, including Egypt, Tunisia, Nigeria, Cameroon, and Mali, among others (ABNE 2017). While Indonesia has completed biosafety assessment of two GE corn and one GE potato variety, these are not yet commercially cultivated (USDA FAS 2020) The list of non-planting countries which granted approvals for import of GE crops for feed, food and processing can be found in the annual reports of International Service for the Acquisition of Agricultural Biotechnology (ISAAA). According to ISAAA (2018), Iran approved import of $\mathrm{GE}$ rice, soybeans and rapeseed from 1996 till 2016; Malaysia approved canola and potato for food, cotton for clothing, maize and soybeans for animal feed. 
as animal feed and become ingredients in hundreds of types of industrially processed food (Atalan Helicke 2015: 663-664).

Turkey, ${ }^{3}$ the subject of this paper, is one of the top ten ranking countries in terms of halal food markets (\#9), halal pharmaceuticals and cosmetics (\#9), modest fashion (\#2), and Muslim friendly travel (\#3) (Dinar Standard 2019: 13). It has been importing GE corn and soy as animal feed since 2011. Turkey's Biosafety Law, which came into force in 2010, requires the monitoring of GE animal feed and their products, and labeling them from a GE content threshold of $0.9 \%$ and above. It does not, however, require labeling any food destined for human consumption with GE content. ${ }^{4}$

The literature shows that household food-related labor (e.g. planning, preparation, clean up) falls universally and unevenly on women (Cairns and Johnston 2015). Earlier involvement of women in food-related activities are further enhanced by the traditional roles of motherhood and caregiving, as well as culturally articulated contemporary standards of being a good mother, responsible caregiver and a healthy woman (Cairns and Johnston 2015: 4-6). In such a context, it would not be a surprise to find that women's food preferences and perceptions matter greatly. Studies about food preferences among consumers in the West, for example, have found that $\mathrm{GE}$-free food preference is highest among female consumers (Bellows et al. 2010). There are limited studies examining halal preferences among male and female consumers. Khalek and colleagues' (2015) study with 255 Malaysian consumers (ages 16-35) found that there is 'a significant difference between male and female consumers in their intention to choose halal food', and women showed more concern about their food choices (p: 94).

The article is based on the data collected in Turkey using qualitative methods during the summers of 2015 and 2019. Thirteen focus groups were carried

3 Turkey is a major exporter of agricultural products to other oIC countries (Dinar Standard 2019). Turkey has also played a central role in the development of the standards issued by the Standards and Metrology Institute for Islamic Countries (SMIIC), a subsidiary body of the oIC. (Armanios and Ergene 2018: 135).

4 The current Biosafety Law and Regulation 5977 on Genetically Modified Organisms and their Products, in force since 2010, prohibits the use of GE organisms for baby food specifically, and specifies labeling requirements for the animal feed and monitoring of animal feed based on the import of the approved GE varieties in Turkey (Official Gazette 2010). The Ministry of Agriculture and Forestry of Turkey specifies that the monitoring and controlling requirements apply to three categories only (baby food, soy bean and products, and maize and products) and there is no requirement for labeling of food designated for human consumption because 'there is no approved GE organism for direct human consumption' (Ministry 2019). 


\section{Participants \% (number) Participants \% (number)}

\begin{tabular}{lll}
\hline & $\mathbf{2 0 1 5}\left(\right.$ Total $\left.\mathbf{n}=\mathbf{5}^{6}\right)$ & $\mathbf{2 0 1 9}($ Total $\mathbf{n}=\mathbf{2 7})$ \\
\hline $\begin{array}{l}\text { Secondary or primary } \\
\text { \& secondary }\end{array}$ & $48 \%(\mathrm{n}=13)$ \\
$\begin{array}{l}\text { High school } \\
\text { University and/or }\end{array}$ & $28.5 \%(\mathrm{n}=16)$ & $29.6 \%(\mathrm{n}=8)$ \\
higher & $61 \%(\mathrm{n}=34)$ & $22.4 \%(\mathrm{n}=6)$ \\
\end{tabular}

out with 83 women: 9 focus groups with a total of 56 women in the cities of Ankara and Konya in the summer of 2015, and 4 focus groups with a total of 27 women in the cities of Ankara and Balikesir in the summer of 2019. The participants also completed a survey including 12 questions about their socio-economic status, education, shopping preferences for organic and halal food, and knowledge of GE food as well as sources of information about healthy food. The age range of participants in 2015 was 27-64, and 19-74 in 2019. All of the participants lived in urban areas. All of the participants except two (one in 2015, one in 2019) were married. In addition, 48 participants (84 percent) of 2015 focus groups, and 25 participants (92 percent) of 2019 focus groups had a child (or grandchild) under the age of 18 living in the same household at the time of research. The educational attainment of participants was higher in 2015 compared to those in 2019 (Table 1). All focus groups were carried out in Turkish. The quotes were translated to English by the author. All names were anonymized.

\section{Tayyib-Halal Food: Ethics, Environmental Sustainability and GE Food}

GE crops have been commercially available in the world since the mid-199os. Due to the complexity of the methods used and their impacts on human health, the approach to GE food shows great variance among countries and within countries, and involves science, economics and religion (Atalan-Helicke, 2015; Kurth and Glasbergen 2017). Since the early 20oos, various bodies of Islamic scholars have declared that basic genetic engineering of food is acceptable as long as no haram substances have been used (IWISA 2012). In 2010, the Malaysian Biotechnology Information Center (MABIC) and the International 
Halal Integrity Alliance organized an international workshop for Islamic scholars and concluded that Islam supports beneficial scientific innovations for humans, and that genetic engineering methods used in plant improvement are not different from other plant improvement techniques from the shariah point of view. Whereas Islamic scholars considered the permissibility of GE food by focusing on the methods of genetic alteration, ${ }^{5}$ from the framework of maqasid al-shariah (the purposes of Sharia), on the grounds of necessity (Dharurah), chemical transformation (Istihalah), and combining permissible and non-permissible sources initially, they also considered the possibility and ethics of transgenic animals (Al Attar 2017; Bouzenita 2018; Bouzenita and Mirghani 2014; Gunay and Ozdemir 2016).

Muslim scholars and consumers also frame opposition to GE food using Islamic principles and ethics. They draw on such principles in terms of health, food safety, environmental stewardships and questions of fair trade. Bouzenita (2010) examines the methods of genetic alteration and the implications of even the smallest change in genetic material from an Islamic law perspective, and raises at least two objections for the acceptability of GE food as halal. The first objection concerns istihlak (mixing pure and impure substances); although this notion can be used to assess the permissibility of accidental mixing of impure substances into food, Bouzenita (2010) insists that it cannot apply to the intentional combination and large-scale industrial production of such genetically altered food. The alteration at the genetic level may be small, but the notion of 'a mixture of minimal substance' can be misleading due to the role that the relevant gene, enzyme or protein plays in the organism. The second objection is related to the al jallah principle - the effect of a permissible animal feeding on impure food. Today, the global meat production is dependent on GE animal feed (van Eenennaam 2013:2), and without further research on its impacts on human body, there is a concern about the transferability of the GE animal feed to humans. ${ }^{6}$

5 The most common commercially available GE traits of insect resistance and herbicide tolerance are produced through the method of transgenesis. Transgenesis allows genes and DNA sequences to be moved between any species (e.g. insertion of Bacillus thuringiensis (Bt)-toxin gene into corn for resistance to European corn borer). (Holme et al. 2013) Other genetic modification methods include cisgenesis, which involves using a gene pool identical to the gene pool available for conventional breeding or introduction of native genes from a crop's own gene pool (ISAAA 2014), and genome editing, that uses a series of technologies, such as CRISPr-Cas9, to silence or edit an organism's DNA. Current research and expansion efforts also focus on drought tolerant varieties. (ISAAA 2019b).

6 So far, any impact on the human body is undetectable. Van Eenennaam (2013), who examined the costs and benefits of GE agriculture for livestock, argued that studies 
In Islam, there are different approaches to animals feeding on impure food. One approach takes the view that the animal does not become impure in any way by consuming impure food. A second approach does not resolve the animal's status, but discourages feeding animals with impure food. A third approach assumes a reversible impurity, and judges that the meat of an animal that has fed on impure food may be consumed after a certain period of confinement. Bouzenita (2010) takes a stronger stance than any of these, arguing that even if there is no exchange of mutation in the genetic blueprint of either the GE food or the animal that feeds on it, GE food disturbs the balance that Allah has created by deliberation and may lead to unforeseeable and unchangeable consequences both for humans and ecosystems (p.25). Such concerns about ecosystem effects also connect with recent scientific studies related to field evolved resistance of pests ${ }^{7}$ and resistant weeds. ${ }^{8}$ These problems have broader impacts for agriculture and food security, and have been raised by anti-GE food activists worldwide. ${ }^{9}$

The Turkish non-profit organization, Gıda Güvenliği Hareketi (Association of Health and Food Safety Movement), which has been a leading voice of the Islamic anti-GE food movement in Turkey since 2008, opposes GE agriculture due to health and food safety concerns. The president of the association, Kemal Özer, argues that the quest for clean and halal food involves complex processes that

conducted to look for the presence of recombinant DNA (rDNA) or the protein encoded by the rDNA in the milk, meat and eggs from animals fed GE crops found no expression of the rDNA or proteins. Another study by Vicini and colleagues (2019) reviewed multiple methods assessing glyphosate in feed residues and animal health, and found that 'glyphosate use in crops fed to poultry and livestock has not affected animal health, rumen/gut microbes' (p: 4509). However, the same study also points to the limitations of empirical models and the need to evaluate risks in the context of 'realistic exposures and conditions' (4515).

7 Studies have demonstrated growing field-evolved resistance to $\mathrm{GE}$ crops expressing Bacillus thuringiensis $(B t)$. Bt is a species of bacteria that lives in soil and makes proteins that are toxic to some insects when eaten. Crops integrated with Bt toxins have been effective initially by controlling target pests while allowing a reduction in insecticide use in largescale monoculture operations. However, field-evolved resistance indicates that insects have become resistant to Cryı toxins in Bt corn and to CrtıAc toxins in Bt cotton in places including South Africa, Puerto Rico, Brazil and the continental USA. (Tabaschnik 2015).

8 Also known as 'Roundup Ready' (RR), herbicide tolerant crops incorporate glyphosate, a non-selective, systemic herbicide that controls more weed species than any other herbicide (Heap and Duke 2018, 1040). However, studies show that since 1996, 38 weed species distributed across 37 countries have evolved resistance to glyphosate. (Powles 2008; Heap and Duke 2018).

9 There is a significant body of literature on anti-GE food activism. See Bawa and Anilakumar (2013) for a review; Kinchy (2012) for the intersection of science and politics in anti-GE food activism; and Kurzer and Cooper (2007) for European Union countries. 
should involve the very genetic structure of the food. Quoting the verses of the Quran, Baqarah 29 (2:29) and Ibrahim 34 (14:34), Özer (2010:196-197) argues that Allah has given all the sustenance $($ Rizq $)$ for humans, but humans are destroying nature and balance (mizan) as well as their own values by altering God's creation and intervening into fitrah. Özer continues that chemicals used in GE agriculture turn the human body and the environment into a waste dump (p.196), while multinational companies reap financial gains. Similar to the critique of role of multinations in GE agriculture, Büyüközer (2012) argues that GE food is anti-Islamic as Islamic law argues for trade to be fair, but GE is not. GE crop research and marketing involves large biotechnology firms controlling a big share of the market (Atalan Helicke 2015: 667). From these perspectives, not only the Islamic principles about genetic alteration but also the socio-economic concerns about GE agriculture undermine its tayyib-halal status. Özer's concerns are shared by other Turkish scholars: In a retreat of religious scholars organized by the Turkish Directorate of Religious Affairs in 2011, one Turkish theologian argued that it would be wrong to define GE food as haram but 'one can tell that GE food is not tayyib' due to the difficulty of assessing 'where the alteration starts' (Beşer 2011: 78 ) and the broader impacts of that alteration.

Despite standardization initiatives among states, businesses and nonprofit agencies, the understanding and practice of halal requirements vary. This fragmentation of halal certification is particularly significant in terms of GE food. Although they do not explain why, two of the halal standards used by five certification bodies in Netherlands prohibit the use of GE organisms in food (Kurth and Glasbergen 2017). In Turkey, GIMDEs (Association for the Inspection and Certification of Food and Supplies), a halal certification agency and a non-profit engaged in consumer education and advocacy, implements confinement periods for animals fed GE feed before slaughtering them (Atalan Helicke 2015: 669). State-led halal certification agency, Turkish Standards Institute (TSI), also an important actor for regional and global halal meat markets, declares 'halal certification will not be issued for GE food destined for human consumption. ${ }^{10}$ However, a recent discussion in the Turkish parliament revealed the vagueness of the statement and the complexity of the debate regarding GE food and GE animal feed: The Institute exempts GE animal feed from the category of 'direct' human consumption and thus 'food' (твмм 2017). While this statement derives from the existing 2010 Law and Legislation on GE organisms in Turkey, it does not address

10 Turkish Standards Institute Halal Standards. https://tse.org.tr/IcerikDetay?ID=41\&Paren tID=34. (Accessed December 20, 2019). 
consumer concerns about the transferability of the GE-material to humans through consumption of animals fed on GE-feed.

As Muslim consumers seek quality, they juxtapose more natural and local foods against industrialization and globalization. Embedded in these juxtapositions are assumptions that the higher the natural content of food and the more local it is, the less susceptible it will be to malign human interference. Focusing on 'green halal', an organic and halal food movement in Belgium emphasizes 'ethical, responsible, mindful consumption' and animal welfare approved meat. Other 'eco-halal' initiatives (such as the Norwich Meadows Farm in upstate New York, USA) integrate organic and halal farming respecting labor justice and non-GE agriculture. Highlighting these examples from Belgium and the USA, Iqbal (2015) argues that these initiatives show the desire of Muslim consumers, producers and business for sustainability. Moreover, GE-free, organic and halal statuses represent additional messages about health and safety, and cater to a specific group of health-conscious consumers who seek to buy 'what is best for themselves and their families' (Armanios and Ergene 2018: 209). These narratives can also be seen through the case study of women consumers in Turkey.

\section{Case Study: Women Consumers and Access to Clean and Healthy Food in Turkey}

The research participants came from diverse socio-economic backgrounds. In $2015,61 \%$ of research participants had a university degree or higher, while $22 \%$ of participants in 2019 had a university degree or higher. In 2019, almost half of the participants (48\%) had a secondary degree as their highest educational level. The educational attainment is correlated to income as education provides employment and higher-paying job opportunities: In 2015, 6o percent of the participants $(n=33)$ were full-time employed, whereas only 29 percent of the participants $(n=8)$ were full-time or part-time employed in 2019. In 2015, 42.8 percent of participants earned more than 1500 USD monthly (Table 2), whereas in 2019 , only $18.2 \%$ of participants earned a monthly income more than 1000 USD (Table 3). The participants in 2015 were recruited via online mothering groups and word-of-mouth through key informants. Regarding the representation bias of relatively high income participants in 2015, the participants in 2019 were recruited only through word-of-mouth and key informants with a shift to low and middle income neighborhoods. ${ }^{11}$

11 The loss of Turkish currency against the USD in this period (2015-2019) and problems in receiving inflation-based income adjustments for working class has also affected the 
TABLE 2 Economic status of 2015 focus group participants $(n=56)$

\section{5 focus group participants}

\begin{tabular}{llc}
$\begin{array}{l}\text { Monthly income } \\
\text { (Turkish lira) }\end{array}$ & Monthly income (USD)* & Research participar \\
\hline $1,000-2,500$ & $418-950$ & $35 \cdot 7 \%(\mathrm{n}=20)$ \\
$2,501-4,000$ & $950.1-1,520$ & $21.4 \%(\mathrm{n}=12)$ \\
$4,000+$ & $1,520.1+$ & $42.8 \%(\mathrm{n}=24)$
\end{tabular}

The USD income was calculated based on the Turkish National Bank currency exchange rates of July 15, 2015.

The minimum wage at the time of calculations was 1,ooo Turkish lira/month (418 USD).

\section{9 focus group participants}

\begin{tabular}{lll}
$\begin{array}{l}\text { Monthly income } \\
\text { Turkish lira) }\end{array}$ & $\begin{array}{l}\text { Monthly income } \\
\text { (USD)* }\end{array}$ & $\begin{array}{l}\text { Research parti } \\
\text { Percent }\end{array}$ \\
\hline $1,500-2,500$ & $250-417$ & $48.5 \%(\mathrm{n}=13)$ \\
$2,501-4,000$ & $418-667$ & $14.8 \%(\mathrm{n}=4)$ \\
$4,001-6000$ & $668-1001$ & $18.5 \%(\mathrm{n}=5)$ \\
$6000+$ & $1002+$ & $18.5 \%(\mathrm{n}=5)$
\end{tabular}

The USD income was calculated based on the Turkish National Bank currency exchange rates of May 16, 2019.

The minimum wage at the time of calculations was 2,020 Turkish lira/month (net) (427 USD).

relatively lower incomes of participants in the 2019 field work. Turkey has a history and cycles of economic crisis. The most recent economic crisis of 2018 is characterized by a prolonged recession with persistent low (negative) rates of growth, dwindling investment performance, debt repayment problems, rising unemployment, a spiraling currency depreciation and high inflation (Orhangazi and Yeldan 2020). 
Due to a growing emphasis on health and food in recent years, more consumers learn about $\mathrm{GE}$ food through the media, which promotes both facts and myths (Atalan Helicke 2020). The concerns raised by participants, who are mainly in charge of planning and preparing the food that their family eats, reflect generalized consumer anxieties about the changing agri-food system and GE food in particular. Participants mentioned that they pay attention to the ingredients of the food (e.g. gelatin) as well as the processes by which food was produced. While they were worried about the health effects of agricultural chemicals, hormones and food additives (e.g. cancer, chronic disease, obesity, early menarche), they were also concerned about 'mixed messages' about GE crops from officials, businesses, media and celebrity doctors.

While paying attention to taste, freshness, seasonality of fresh fruits and vegetables, and ingredients in processed items, one issue expressed was the amount of time it takes to be 'vigilant'. Because Turkey is a Muslim majority but secular country, it is presumed that food production and processing follows Islamic rules. However, due to the import-export relationship of Turkey to non-Islamic countries, and the laxity or negligence in controlling these imported products as well as its secular governance structure, questions are raised as to whether the available food is generally permissible as halal. Aysin (29 years old, Konya, 2015) who spends a lot of time reading labels mentioned her concerns about the 'gelatin' used widely in processed food, including clear fruit juices. There are no additional labels, but, she said, 'I need to know that the gelatin comes from halal beef.' She knows that Turkey imports live cattle ${ }^{12}$ and is unsure if gelatin from these animals meets all halal standards.

Another major concern repeated in 2015 and 2019, was about the widespread use of chemicals to produce fruit and vegetables, and the narratives used by officials, farmers and business about the 'impossibility' of agricultural production without chemicals. Fatma (71 years old, Ankara, 2019) mentioned the challenges she faced with the garden she rented to grow vegetables for her family: 'Nothing grows without chemicals. It is not like how it was when I was growing up.' Other participants in the group mentioned the impacts on health, such as 'chronic diseases' and 'increasing rates of cancer' related to these chemicals. A similar concern was about the use of hormones: In Balikesir (2019), Huner (37 years old) who worked in a greenhouse mentioned 'how much the cucumbers

12 Turkey has been importing live cattle to address the shortage of red meat in the domestic market, particularly from Brazil, Uruguay and European Union countries. In 2018, Turkey imported a total of 1.4 million head of cattle, which was 63 percent higher than in 2017 . Turkey also imported live cattle to address the needs during Eid al Adha for sacrifice rituals in 2010, 2011, 2017 and 2018 (USDA 2019). 
grew between collecting times in the morning and the evening!' While she was not sure what kind of 'hormone' the greenhouse owners used, she was concerned about how 'unhealthy' it could be.

Several participants mentioned the difficulty of knowing about all chemicals and learning to get rid of them in their own kitchen when there is a growing number of chemicals with increased potency and toxicity in the food supply. Deniz (47 years old, Ankara, 2015) shared that she felt stressed even after reading every food label. Because her husband had cancer, she said 'I buy only organic food.... I feel that food is the only thing I can control when everything around us is carcinogenic.' While Deniz's remarks reflect her ability to purchase organic food when she can, the privilege associated with organic consumption did not prevent her concerns about the food system.

Referring to the inconclusive scientific studies about health impacts of GE food, Irem (35 years old, Ankara, 2015) mentioned her precautionary approach to avoid GE food. Because her daughter has several allergies and the actual culprit, soy lecithin allergy, was not diagnosed for years, she is concerned about flare ups. So, she paid attention to secondary consumption of soy: 'We buy only one brand of milk because if the cows eat GE feed, then [my daughter] definitely has flare ups.' Others also had their lists of GE food to avoid: A 48-year-old mother in Ankara (2015) said she avoids chicken due to her daughter's pediatrician's suggestion because her daughter has egg and milk allergies. While she 'did not know chicken could contain so many allergens', other participants mentioned how chickens 'now eat GE feed.'13

The diversity of participants in terms of age, educational attainment, income and religious values ${ }^{14}$ (e.g. preference for halal in different categories such as food, cosmetics, tourism) provides a broader perspective in terms of anxieties about the agri-food system and the complexity of negotiating values in food choices. While food is often an emotional topic (Cairns and Johnston 2015: 16-17), the polarization among secular and Muslim citizens in Turkey (Tugal 2012) initially brought another layer of complexity to the focus groups. However, as they shared their individual anxieties around food, and particularly access to wholesome food, participants realized the collective nature of these anxieties transcended an easy secular/devout division.

13 After the 2006/2007 avian flu outbreak, poultry operations in Turkey have become largescale confined operations depending on GE animal feed.

14 Participants were not directly asked whether they are secular or devout Muslims. While some participants had headscarves to represent their religious identity, there were religiously devout participants without headscarves and secular participants with traditional headscarves. (See Gökarkssel and Secor 2010 and Aygül and Gürbüz 2019 for a discussion of different clothing style and connections to class). 
Although domestic consumption of organic food is increasing in Turkey, particularly due to aspirations to lead a healthy life and anxiety about the health of children, it is still limited to environmentally conscious, urban middle- to high-income consumers (Akgüngör, Miran and Abay 2010). Fulya (51 years old, Ankara, 2015) mentioned that 'everything in the organic market looks fresher and is tastier', and she used to shop in organic farmers markets before moving to her new neighborhood. However, Esme (37 years old, Ankara, 2019) complained about the cost of organic food: 'I want to eat and feed my family healthy food. I have Multiple Sclerosis so it is especially important. But organic certified rice at store $[\mathrm{M}]$ is three times the cost of regular rice. I cannot afford it as a household with two incomes. How can other families afford it?'

Other concerns were about the intersection of organic and halal products. Melda (35 years old, Konya, 2015) mentioned that she trusts and consumes organic food for health. Yet, she said she 'trusts halal certified food more' because she was not sure whether organic certification process and agencies follow all of the halal principles. Her choice is then to purchase food products that are both organic and halal certified, such as poultry. However, as ten other participants mentioned, items which have both halal and organic certification label 'are more expensive than organic alone'. (Figure 1) Some participants wished for a single label that would combine the ingredients and qualities that were important to them as halal only covered some aspects. Rusen (35 years old, Konya, 2015) wished for products that were 'natural'. Naile (33 years old, Konya, 2015) shared her wish for a 'healthy' label that would combine halal and organic principles. These findings resonate with some of the tensions in the tayyib-halal movement and scholarly work: Some argue that a greener lifestyle would be burdensome for ordinary people and challenge Islam's core egalitarian spirit (Kamali 2010).

Melda's choices in her quest for clean and healthy food raises new questions about the challenges and possibilities of converging organic certification derived from secular practices with halal certification derived from religion. While consumers' definitions of healthy food suggest an overlap between organic and halal food, the certification agencies' frameworks often do not. In Turkey, organic certification can be issued by private and state agencies following the 2004 State Organic Agriculture Law (number 5262) and Directorate of Organic Agriculture issued in 2010. The organic legislation has extensive rules on animal welfare and plant production (Official Newspaper 2010). Halal certification in Turkey can also be issued by a state agency (TSI) or by multiple private agencies (e.g. GIMDES). Halal certification standards, however, are not uniform: TSI follows the criteria of the OIC Standards and Metrology Institute (OIC/SMIIC 1). GIM DES has been accredited by multiple global halal certification 

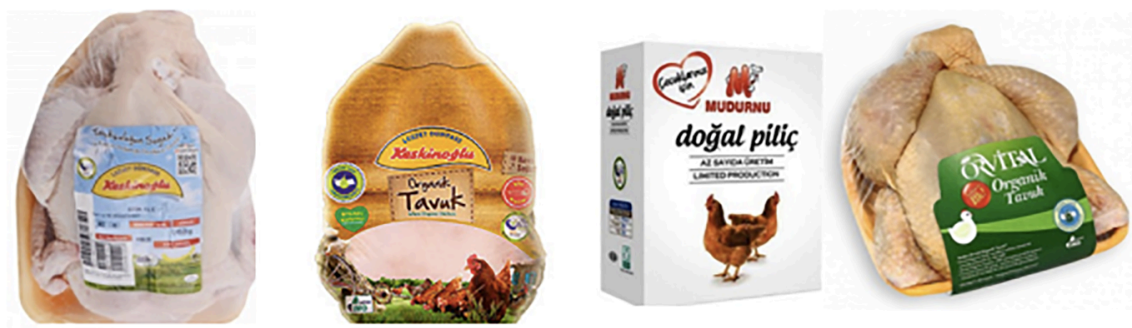

\begin{tabular}{|c|c|c|}
\hline Keskinoglu (conventional) & $7.49 \mathrm{TL} / \mathrm{kg}$ & 3.6 USD $/ \mathrm{kg}$ \\
\hline Keskinoglu (organic and halal)* & $23.90 \mathrm{TL} / \mathrm{kg}$ & $8.1 \mathrm{USD} / \mathrm{kg}$ \\
\hline Mudurnu (natural) & $14.99 \mathrm{TL} / \mathrm{kg}$ & $5.09 \mathrm{USD} / \mathrm{kg}$ \\
\hline Orvital (organic and halal)* & $23.90 \mathrm{TL} / \mathrm{kg}$ & $8.1 \mathrm{USD} / \mathrm{kg}$ \\
\hline
\end{tabular}

(Carrefbur, 03/02/2016, website prices; 1 USD $=2.94 \mathrm{TL}$ )

FIGURE 1 Comparison of prices for different types ${ }^{15}$ of chicken sold in markets. Organic and halal certifications are based on standards (calculated based on 2016 prices in the Carrefour supermarket chain in Turkey)

agencies (e.g. Department of Islamic Development Malaysia JAKIM standards) and uses its own guidelines. Like TSI, GIMDES has also been working to create common standards for global markets (Atalan Helicke 2015: 671).

Halal is often associated with stricter hygiene and food safety standards, particularly in regards to meat. In 2015, almost all participants in Konya and one-fifth of participants in Ankara said they preferred to shop for halal meat. In 2019, one-third of the participants in Ankara said they preferred halal meat. Concerns about meat, however, still surfaced. Turkey is connected to export markets through pork production, and in recent years, there have been concerns about the introduction of pork into the national food supply chain. Sibel (42 years old, Konya, 2015) said her family is particularly suspicious of meat while vacationing (in Turkey) because of what might be offered to foreign tourists. There was also concern that halal meat may not follow tayyib principles. Participants did not specifically use the word 'tayyib' to express their concerns, but talked of 'terms' and 'conditions' that defined food as halal but might not be incorporated into certification standards. Anka (40 years old, Balikesir, 2019) complained about 'the fast pace of production', and said, 'I want meat to come from animals raised without hormones and drugs. Then it would be

15 Here 'conventional' refers to meat products from industrial animal feeding operations without any sustainability or health labels. Certified 'organic' fulfills organic productions standards. Certified 'halal' chicken fulfills halal standards. There is no standard or regulation for 'natural' (doğal) in Turkey, but companies use the label generously. 
halal.' Atiye (30 years old, Ankara, 2019) was not sure about the halal status of meat from mechanized slaughter houses: 'Would meat be halal if you pray once but slaughter 10,000 animals with the same machine?' For Esme (37 years old, Ankara, 2019), the inhumane conditions of imported live animals was a concern: "Those animals lived miserably in that ship. ${ }^{16}$ They will not become halal if you kill them after prayer and letting their blood [according to Islamic principles].' In her focus group, these comments led to a wider discussion of red meat consumption and live meat imports in Turkey, both of which were deemed as a 'problem' and raised questions about the morality of red meat consumption.

Participants generally thought that halal certification implied the absence of GE ingredients, but many shared that they had questioned their own assumptions and the companies from which they purchase. Some women received further guidance in terms of animal feed: Esra ( 36 years old, Konya, 2015) said that she had started shopping for free range and halal chicken due to concerns about GE feed. Later, due to her hodja's suggestion that chicken fed GE feed can be najs (not clean), she stopped preparing chicken for her family. Esra's choices resonated with others: Peri (33 years old, Konya, 2015) was concerned because she was not sure that the halal certified companies where she shops had a monitoring mechanism for GE food: 'It is... not clear what [these companies] think about genetic engineering.... I know corn has GE ingredients. But I did not hear anything about its halal status.' Interestingly, the lack of a clear stance on GE food by companies engaged in halal certification created controversies for consumers in their food choices: Hatice (39 years old, Konya, 2015) mentioned that she used to consume the halal products of a particular company. However, after reading in the newspaper about tests by state officials confirming GE ingredients in the company's food items, she stopped consuming their products. In another focus group, the same company came up: Semiha (34 years old, Konya, 2015) said she visited the company's slaughterhouse: 'It was very hygienic and they follow halal slaughtering practices. Even though they were accused of using GE ingredients, I trust them.' She trusted the halal meat production process and did not care about $\mathrm{GE}$.

16 She refers to the shipment of 27,00o live cattle imported from Brazil in February 2018. There was a scandal when news stories showed animals not provided water for the last two days of their journey and living in cramped and unsanitary conditions. See, for example, Brezilya'dan canlı hayvan getıren Nada gemisi Mersin'e yanaştı [Nada, the ship bringing livestock from Brazil came to Mersin port]. February 25, 2018. https://www.cnnturk.com/ turkiye/brezilyada-canli-hayvan-getiren-nada-gemisi-mersine-yanasti. (Accessed August 31, 2020). 
Women consumers in Turkey are anxious about their food due to ingredients, chemicals as well as processes (e.g. halal slaughtering, GE food). Whereas they shared factors such as their knowledge of GE food or organic food affecting their food choices, they also raised concerns about the price premiums of organic and halal food. The lack of a clear stance on GE food by halal certified businesses in Turkey often frustrated participants in terms of who and what to trust. As women consumers discussed their food choices, several also expressed their wish for an intersection of different certifications, particularly organic and halal, to cater to their expectations of healthy, clean and religiously proper food. These expectations can be viewed as consumers' desire for a broader definition of morally permissible and wholesome food that goes beyond labels and leads to a faith-based sustainable food system.

\section{Discussion}

The complexity of the agri-food system changes consumer anxieties and urges consumers to reflect on their values and their food choices. Whereas some of these concerns can be directly related to increased use of chemicals in agricultural production and the fast pace of production in livestock operations, others are related with lack of knowledge about the long-term impacts (e.g. GE animal feed) on health and the environment. While the expansion of halal certification and its institutionalization provide some assurances for Muslim consumers, broader dimensions of the agri-food system create new questions. GE food is a particularly poignant and complex issue in the food system because it raises questions that can only be answered from an intersection of religious, scientific, business, environmental and social perspectives. Despite declarations by religious authorities in different Muslim countries, including those that have broad institutionalized halal certification (e.g. Malaysia), that GE food is halal, Muslim consumers seek a broader definition of halal that encompasses healthy food - for humans, animals and the earth. This might be described as a quest for wholesome or tayyib food.

Consumer concerns about GE food stem from multiple sources. Moreover, how the halal certification business, the markets and the state deal with GE food raises more questions for consumers and does not alleviate their concerns about whether $\mathrm{GE}$ food is clean and healthy. It may be beyond the scientific knowledge of religious scholars and halal certification agencies to address the complexities of the GE process and its ramifications (Atalan Helicke 2015). These new questions may include the following: What kind of environmental impacts do the alterations at the genetic level of the plant have on nature? 
Does genetic alteration in agriculture mean that humans are intervening with the fitrah and the mizan? What happens to an animal that is fed on GE animal feed? What kind of secondary changes can we talk about in the human body after consuming milk or meat coming from GE animal feed? Is it possible to trace these changes in the human body with scientific studies designed for short-term intervals?

From the consumer perspective, sometimes the regulations fall short of providing assurances. What happens when $\mathrm{GE}$ animal feed and $\mathrm{GE}$ food are subject to different regulations? What happens when there is no labeling requirement and the consumers' right to know is not answered? In other instances, the fragmentation of the halal certification and the diversity of opinions among halal certification agencies about GE food and GE animal feed frustrate consumers (Atalan Helicke 2015). What happens when one halal certification agency says meat from animals fed GE animal feed is halal and another, in the same country, applies confinement periods for animals fed similar diets? For Muslim consumers who seek a more deliberately ethical halal lifestyle in globalized markets, the pace of production and lack of monitoring for animal welfare also becomes a problem: Can the meat be halal if thousands of livestock are imported in unsanitary conditions and face miserable conditions on a ship sailing thousands of kilometers before they are sent to facilities for halal slaughter and processing?

These and similar questions were raised by the participants in focus groups in Turkey in 2015 and 2019. Rather than conclusive answers, as participants shared their concerns, their questions led to deeper conversations about the ethics of meat consumption (both from environmental sustainability and religion lens) and the agri-food system transformations in Turkey. As the participants shared their visions for structural changes that could provide more assurances for consumers through different institutions, the collective nature of their anxieties drew women closer regardless of their consumption patterns, class or levels of religious devotion. Together they imagined alternatives to a system that had not incorporated their inputs.

As participants voiced their concerns, it became clear that the price premiums associated with organic and halal certified products also frustrate consumers and create a burden on food choices. Rather than separate certifications that cater to different issues in the food system, consumers' desire for a 'wholesome', clean and healthy label highlights the need to draw alliances within the alternative food network. Such alliances can also be critical to bring about structural changes in the agri-food system, and to help capture Islam's true egalitarian and ethical spirit while balancing economic, social, ecological and religious values in the quest for clean and healthy food. 


\section{Acknowledgements}

The paper would not be possible without the contributions of research participants and family, friends and colleagues in Turkey. I want to thank Nuriye Atalan, Filiz Tutku Aydın, Nurdan Atalan Çayırezmez, Rabia Çemrek, Nurten Çevik, Süheyla Sarıtaş and Gülüş Gülcügil Türkmen, who helped to recruit participants and coordinate logistics for focus groups. Melek Nur İndibi, Serihan Güner and Mehmet Çayrrezmez helped with the transcriptions. A Skidmore College Faculty Development Grant funded the field work in 2015. I want to thank the organizers of the 'Halal and Tayyib: Rethinking the Ethical' conference at the Zaytuna College Center for Ethical Living and Learning, where I presented an earlier version of this paper. I thank Rano Turaeva and Michael Brose at the Max Planck Institute for organizing the Halal Economies in NonMuslim Societies workshop, and the conversations that helped shape this paper. Finally, I thank two anonymous reviewers for their helpful feedback, and Jennifer Cash for the editorial comments.

\section{References}

ABNE (2017). African Biosafety Network of Expertise: Status of Crop Biotechnology in Africa. http://nepad-abne.net/biotechnology/status-of-crop-biotechnology-inafrica/. (Accessed August 31, 2020).

Akgüngör, Sedef, Bülent Miran, and Canan Abay (2010). Consumer willingness to pay for organic food in urban Turkey. Journal of International Food \& Agribusiness Marketing, 22(3-4): 299-313.

Al-Attar, Mariam (2017). Food ethics: A critique of some Islamic perspectives on genetically modified food. Zygon ${ }^{\circ}$, $2(1): 53^{-75}$.

Armanios, Febe and Bogac Ergene (2018). Halal Food: A History. New York: Oxford University Press.

Atalan-Helicke, Nurcan (2015). The halal paradox: negotiating identity, religious values, and genetically engineered food in Turkey. Agriculture and Human Values 32(4): 663-674.

Atalan-Helicke, Nurcan (2020). Access to clean and healthy food in Turkey: Food activism and mothers' concerns about shopping for change. In, Rebecca RichardBromwich, Noemie, Olivia Ungar, Melanie Younger and Maryellen Symmons (eds.), Environmental Activism and the Maternal: Mothers and Mother Earth in Activism and Discourse. Toronto: Demeter Press.

Aygül, Hasan Hüseyin and Gamze Gürbüz (2019). Tüketim, moda ve Islami giyim açısından tesettürlü/türbanlı öğrenciler: Akdeniz Universitesi Örneği 
[Consumption, fashion and Islamic clothing: Women with a veil, case study of Akdeniz University]. Muhafazakar Dusunce/Conservative Thought, 15(56): 161-209.

Bawa, A. S., and K.R. Anilakumar (2013). Genetically modified foods: safety, risks and public concerns - a review. Journal of food science and technology, 50(6), 1035-1046.

Bellows, Anne C., Gabriela Alcaraz, and William K. Hallman (2010). Gender and food, a study of attitudes in the USA towards organic, local, US grown, and GM-free foods. Appetite, 55(3): 540-550.

Beşer, Faruk (2011). Güncel Dini Meseleler İstişare Toplantısı (Proceedings of the Debates on Current Islamic Issues). November 26-28, 2011. Directorate of Religious Affairs, Prime Ministry of Turkey. Ankara: Diyanet İşleri Başkanlığı Yayınları.

Bouzenita, Anke Iman (2010). Islamic legal perspectives on genetically modified food. American Journal of Islamic Social Sciences, 27(1): 1-30.

Bouzenita, Anke Iman. (2018). The most dangerous idea? Islamic deliberations on transhumanism. Darulfunun Ilahiyat, 29(2): 201-228.

Bouzenita, Anke Iman and Mohammed E.S. Mirghani (2014). Transgenic organisms (chimeras) and their Islamic evaluation. Sci.Int., 26(4): 1639-1641.

Büyüközer, Huseyin (2012). Yeniden Gıda Raporu: Yediklerimiz, Içtiklerimiz Helal mi Haram mı ve Sağlı̆̆ımıza Ne Kadar Uygun? [New Food Report: Are the Food and Drinks We Consume Halal or Haram and How Healthy Are They?]. Istanbul: Cevik Matbaacılık.

Cairns, Kate, and Josée Johnston (2015). Food and Femininity. New York: Bloomsbury Publishing.

Dinar Standard (2019). State of the Global Islamic Economy 2019/2020: Driving the Islamic Economy Revolution 4.o. The 7th Annual Report, in partnership with Salaam Gateway. https://cdn.salaamgateway.com/special-coverage/sgie19-2o/fullreport.pdf. (Accessed December 20, 2019).

FDA 2018. United States Food and Drug Administration: How FDA regulates food from genetically engineered plants? https://www.fda.gov/food/food-new-plant-varieties/ how-fda-regulates-food-genetically-engineered-plants. (Accessed December 20, 2019).

Fischer, Johan (2011). The Halal Frontier: Muslim Consumers in a Globalized Market. New York: Palgrave Macmillan.

Friedlander, Krystina (2014). Talking Chop: An interview with Imam Khalid Latif. https://beyondhalal.org/talking-chop-interview-imam-khalid-latif/. (Accessed February 28, 2019).

Gökarıksel, Banu and Anna Secor (2010). Islamic-ness in the life of a commodity: veiling-fashion in Turkey. Transactions of the Institute of British Geographers, 35(3): $313-333$. 
Günay, H. Mehmet and Merve Özdemir (2016). İslami Açıdan Genetiği Değiştirilmis Ürünler [Genetically Modified Organisms from the perspective of Islam].Journal of International Social Research, 9(45): 1004-1022.

Heap, Ian and Stephen O. Duke (2018). Overview of glyphosate-resistant weeds worldwide. Pest Management Science 74(5): 1040-1049.

Holme, Inger Bæksted, Toni Wendt, and Preben Bach Holm (2013). Intragenesis and cisgenesis as alternatives to transgenic crop development. Plant Biotechnology Journal, 11(4): 395-407.

Iqbal, Noor Fatima Kareema (2015). From permissible to wholesome: Situating Halal organic farms within the sustainability discourse. Islamic Sciences, 13(1): 49-56.

ISAAA (2017). Brief 53: Global status of commercialized Biotech/GM crops in 2017: Biotech crop adoption surges as economic benefits accumulate in 22 years. http:// www.isaaa.org/resources/publications/briefs/53/download/isaaa-brief-53-2017. pdf. (Accessed February 28, 2019).

ISAAA (2014). Late blight resistant potato developed using cisgenesis approach. http:// www.isaaa.org/kc/cropbiotechupdate/article/default.asp?ID=1239o. (accessed February 28, 2019).

ISAAA (2018) ISAAA in 2018: Accomplishment Report. https://www.isaaa.org/resources/ publications/annualreport/2018/pdf/ISAAA-Accomplishment_Report-2018.pdf (Accessed November 17, 2020)

ISAAA (2019a). Biotech crops continue to help meet the challenges of increased population and climate change. https:/www.isaaa.org/resources/publications/ briefs/54/executivesummary/default.asp (Accessed August 31, 2020).

ISAAA (2019b). Pocket K No. 54: Plant breeding innovation: CRISPR-Cas9. http://www.isaaa. org/resources/publications/pocketk/54/default.asp. (Accessed December 20, 2019).

IWISA (2012). Workshop resolution. In Shaiks Mohd Saifuddeen and Salleh (eds.), Proceedings of the 2010 International Workshop for Islamic Scholars on Agribiotechnology (IWISA): Shariah Compliance, pp. 53-54. Selangor: MABIC; Los Banos and Laguna: ISAAA.

Khalek, Aiedah Abdul, Sharifah Hayaati Syed Ismail, and Hairunnisa Mohamad Ibrahim (2015). A study on the factors influencing young Muslims' behavior intention in consuming halal food in Malaysia. Jurnal Syariah, 23(1): 79-102.

Kinchy, Abby. (2012). Seeds, science, and struggle: The global politics of transgenic crops. Cambridge, MA: MIT Press.

Koenig, Leah (2008). Reaping the faith. Gastronomica, 8(1): 8o-84.

Kurth, Laura and Pieter Glasbergen (2017). Serving a heterogeneous Muslim identity? Private governance arrangements of halal food in the Netherlands. Agriculture and Human Values, 34(1): 103-118.

Kurzer, Paulette and Alice Cooper. (2007). Consumer activism, EU institutions and global markets: The struggle over biotech foods. Journal of Public Policy, 103-128. 
Ministry of Agriculture and Forestry (2019). GDoya yönelik resmi control çalışmaları (Official monitoring of genetically modified food). https://www.tarimorman.gov.tr/ Konu/1437/GDO-Resmi-Kontrol. (Accessed December 20, 2019).

Mutmainah, Lu'liyatul (2018). The role of religiosity, halal awareness, halal certification, and food ingredients in the purchase intention of halal food. Journal of Islamic Economics, Finance and Banking, 1(1\&2): 33-50.

Official Gazette (2010). Tarim ve Köyişleri Bakanlığı. Genetik Yapısı Değiştirilmiş Organizmalar ve Ürünlerine dair yönetmelik [Ministry of Agriculture and Village Affairs. Regulation on Genetically Modified Organisms and Products] https://www. resmigazete.gov.tr/eskiler/2010/o8/20100813-4.htm. (Accessed December 20, 2019).

Orhangazi, Özgür and Erinç Yeldan (2020). Re-making of the Turkish Crisis. University of Massacchusetts Amherst Political Economy Research Institute, Working Paper Series 504. https://www.peri.umass.edu/publication/item/1254-re-making-of-theturkish-crisis (Accessed October 30, 2020).

Özer, Kemal (2010). Deccal tabakta: Siyasi, dini ve vicdani acidan GDo (The Devil on the Plate: Gmos from a Political, Religious, and Conscience Perspective). Istanbul: HayyKitap.

Powles, Stephen B. (2008). Evolved glyphosate-resistant weeds around the world: Lessons to be learnt. Pest Management Science: formerly Pesticide Science, 64(4): $360-365$.

Tabashnik, Bruce E. (2015). ABCs of insect resistance to Bt. PLoS Genetics, 11(11): 1-5. DOI:10.1371/journal.pgen.1005646.

USDA FAS. (2019). Agricultural Biotechnology Annual: Egypt Lacks Biosafety Framework for the Commercialization of GE Crops. https://apps.fas.usda.gov/ newgainapi/api/Report/DownloadReportByFileName?fileName=Agricultural\%2O Biotechnology\%20Annual_Cairo_Egypt_10-20-2019. (Accessed August 31, 2020).

USDA FAS. (2020). Agricultural Biotechnology Annual Indonesia: Biotechnoloy and Other New Production Technologies. https://apps.fas.usda.gov/newgainapi/ a pi / Report / DownloadReportByFileName?fileName=Agricultural\%20 Biotechnology\%20Annual_Jakarta_Indonesia_10-20-2019. (Accessed October 30, 2020).

Van Eenennaam, Alison L. (2013). GMOs in animal agriculture: Time to consider both costs and benefits in regulatory evaluations. Journal of Animal Science and Biotechnology, 4: art. 37. Available online, https://jasbsci.biomedcentral.com/ articles/10.1186/2049-1891-4-37.

Vicini, John L., William R. Reeves, John T. Swarthout, and Katherine A. Karberg (2019). Glyphosate in livestock: Feed residues and animal health. Journal of Animal Science, 97(11): 4509-4518. 